and to show their relation to the phenomena of dreaming and sleep-waking. From these simpler states it is so much easier to pick out the thread which unites the whole.

Newcastle-upon-Tyne.

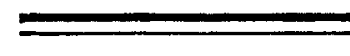

A NOTE ON

\section{THROMBOSIS IN THE VEINS OF THE PELVIS AND LOWER EXTREMITIES AFTER OPERATIONS.}

BI K. G. LENNANDER, HoN. F.R.C.S. ENG., PROFESSOR OF SURGERT IN THE UNIVERSITT OF UPSALA.

(Translated from the Swedish by I. Walker Hall, MI.B. Fict., Senior Demonstrator of Physiology, Orens College, Manchester.)

SOME remarks of mine upon this subject appeared in the Upsala Lakare Forenings Förhandlingar of January, 1899, and in the Centralblatt für Chirurgie, 1899. The results obtained during 18 months following July, 1897, led me to suggest that after every herniotomy or abdominal operation the patient's bed should be raised at its lower end some 10 to 50 centimetres (from 4 to 19 inches) in order mechanically to assist the venous blood flowing from the lower extremities towards the heart, and so preventing thrombosis. This could be best accomplished by placing square pieces of wood under the feet. By such means the change in the position of the body caused the blood to flow along a plane inclined towards the inferior vena cava, and if the shoulders were not raised equally so towards the right auricle. Such a raising of the bed must therefore also make the flow of the blood from the veins in the true pelvis and from the exterior genitals more rapid than in the horizontal position. When the blood-stream has reached the inferior vena cava it will certainly be impelled towards the heart by the negative pressure in the thorax at every inspiration. Since January, 1899, this procedure has been adopted up to date in my practice and no case of thrombosis in the pelvic or lower extremity veins has occurred during three years. As a rule the foot of the bed is raised from 15 to 30 centimetres (from six to 12 inches) but during convalescence it can be lowered to from 10 to 15 centimetres (from four to six inches), and the latter height ought to be maintained in many cases even when the patient has returned home. In cases of cardiac lesions or cardiac debility and in those of local venous changes the elevation is even more important. The elevation should then be from 25 to 40 or 50 centimetres (from 10 to 15 or 19 inches) for the first few days. Cardiac tonics, digitalis, camphor, strychnine, and subcutaneous or intravenous saline injections should be administered before and after narcosis in all cases of cardiac debility. With famished and emaciated patients subcutaneous injections may be given of from 500 to 1000 cubic centimetres (from 17 to 35 ounces) of solution of grape sugar (strength from 5 to 10 per cent.), as well as injections of olive oil, from 50 to 200 cubic centimetres (from one and a half to seven ounces) in 24 hours with from 2 to 3 per cent. of alcohol. The injections can be given in such a way that from 5 to 10 per cent. dextrose and from 2 to 3 per cent. alcohol may be added to normal saline solutions, but 10 per cent. dextrose solution causes pain during and after injection and shows a little sugar in the urine. It is equally important to suit the narcosis as far as possible to the patient's condition (viz., morphia, $\mathrm{CHCl}_{3}$, ether combined with local anæsthesia, \&c.) in order to maintain the circulation and in this way prevent thrombosis.

According to Ziegler thrombosis is caused (1) by slowing of the blood-stream, and (2) by local vascular changes. In laparotomy and hernia patients there are several conditions leading to slowing of the blood-stream and more particularly in the veins of the lower extremities. Many have weak hearts from long illness and are feeble almost to starvation point. Hence after the anæsthetic one often fears fatty degeneration of the cardiac muscle. Furthermore the circulation in the calf of the leg in weak patients may be almost stagnant from the continued supine position, and if there are any varicose veins (especially saccular, where the sacs communicate with the main vessel by narrow orifices) the blood readily stagnates. Laparotomy patients are also frequently troubled by more or less "meteorism" and each increased tension of the bowels increases the intra-abdominal pressure, diminishes the extent of inspiration, lowers the negative intra-thoracic pressure, and so lessens all the forces which promote the venous flow from the iliac veins to the right auricle.

Local vascular changes, phlebitis, fatty degeneration of the endothelium, \&c., may be primarily local, or secondary to infective or autotoxic conditions. Primary vascular changes are always found in patients with varices and in those who have recently suffered from blood clotting. I believe that nothing predisposes more to thrombosis after operations than previous coagulation in the larger veins of the lower extremity or pelvis. Experimental and microscopical evidence points to the probability that a thrombus in circulating blood commences from deposits of the blood plates ("Blutplaettchen") on the vessel walls, between which a small or large number of leucocytes are found. This gathering together of small granules is called "conglutination" by Eberth. If the blood-stream is sufficiently slow coagulation may ensue from the fibrin ferment which is set free from the white blood corpuscles during the act of conglutination. As the result of this united conglutination and coagulation the vessel lumen is rapidly occluded Distally the coagulation extends in the vessels to the nearest large branch, where the blood-stream is again free Proximally the blood will also be clotted if the local circulation is sufficiently slow. Hence, we may find a thrombus extending very quickly from the foot all the way upwards through the crural to the iliac veins in a patient who at first only complains of pain in the calf.

In flowing blood fibrin ferment is very quickly destroyed, hence a rapid or normal circulation ensures such destruction. If we then wish to prevent the formation or spreading of a thrombus it is necessary to combat all causes of local stasis. For the pelvic and lower extremity veins the raising of the lower end of a patient's bed should be of considerable mechanical assistance in promoting the flow of blood towards the inferior vena cava and right auricle. The value of this aid may be increased and the patient made more comfortable by frequently altering his position in the bed, and lightly rubbing the feet and legs, provided that he has not already a thrombus. If any varices exist on the distal side of the operation wound in a lower extremity the part should be bandaged from the foot to such a point, the leg should be elevated, or, better, the bed should be raised. This pro. cedure exerts a very much more noticeable influence upon the circulation. By its use I believe we may largely prevent thrombosis following surgical operations, parturition, and those diseases which are accompanied by intense anæmia and auto-intoxication, in which a tendency towards the com. plication of thrombosis exists.

I consider myself also entitled to ask physicians to use this suggestion of " bed elevation" for preventing thrombosis. Anæmic patients often rest and sleep better after such an arrangement of the bed. Patients with medium. sized varices on their feet or legs if their limbs have not been bandaged during the day often feel restless and tired with aching in their legs at bedtime and are consequently unable to sleep for several hours. For such persons an elevation of from eight or 12 to 15 centimetres (from three or four and a half to six inches) should be employed at night. After a few nights' experience of the position in question these patients will sleep better and the unpleasant sensations in their limbs will entirely disappear. Upsala.

The Medical Department of Mc Gill UniverSITX.-Some $\$ 60,000(£ 12,000)$ is now being expended in new class-rooms which are to be ready for the opening of the regular session in October. When the call to arms came for volunteers to serve the Empire in the Sonth African campaign McGill University sent many of her students and not a few from the medical department. Two of these hare met a soldier's death and now fill honoured soldiers' graves in that far south land-Mr. E. P. O'Reily, son of Dr. O'Reily of Hamilton, Ontario, and Lieutenant Border, the only son of Canada's Minister of Militia, himself an M.D. McGill can be consoled in her loss by the thought that her two sons have died fighting fcr Queen and Empire. 
HEATSTROKE IN INDIA : AN EXAMINATION OF SOME STATISTICS RELATING THERETO.

BY W. J. BUCHANAN, B.A., M.B., D.P.H. DUB., MAJOR, I.M.S. ; OFFICLAL STATISTICAL OFFICER TO THE GOVERNMENT OF INDIA IN THE MEDICAL DEPARTMENT,

THE purpose of this paper is not to discuss the whole question of the occurrence of heatstroke in India but rather to find out how far certain statements made in Dr. Sambon's article on "Sunstroke as an Infectious Disease" are borne out by an examination of the medical statistical records of the European army in India-statements which have proved so "infectious" that they have been repeated with but little discrimination in several recent publications dealing with the disease. The first criticism suggested by a perusal of Dr. Sambon's article is that one is somewhat at a loss to find out how from available records Dr. Sambon was able to discriminate between cases of syncope produced by heat and the more severe form of heatstroke to which he wishes to give the name "siriasis," a term which savours more of atmospheric influences than Dr. Sambon should care to countenance. It is easy to say that cases which do not seem to agree with one's theory "are only cases of syncope." In order to avoid this error in the following tables I have taken only fatal cases of heatstroke. Dr. Sambon says that in syncopal cases "immediate recovery is the rule," therefore we are safe in concluding that the fatal cases recorded in the following tables are examples of what he would call "siriasis," but which we prefer to call by the expressive and simpler name of " heatstroke." Dr. Sambon has fallen foul of the expression " heatapoplexy," which, bowever, is the term sanctioned by the Royal College of Physicians of London in their "Nomenclature of Diseases," the use of which is officially enjoined for all medical statistical returns in India. Dr. Sambon may be assured that medical men in India do not confuse the cases they call heat-apoplexy with cerebral hæmorrhage or other such disease.

The statements of Dr. Sambon which will be here examined are as follows:-1. New arrivals are more liable to be attacked than natives or old residents ...... acclimatisation reduces the susceptibility to siriasis. 2. Siriasis is not always found in the warmest regions. 3. Siriasis prevails only in the "lowest regions," in "coast districts," or in the valleys of great rivers. 4. Its altitudinal range is even more restricted than that of yellow fever-this range is put down by Manson (p. 206) and by Allchin ("Manual of Medicine," vol.i., p. 13) as 600 feet. 5. It is prevalent in Lower Burma.

Taking the first statement we admit at once that Europeans newly arrived in India are more liable to be attacked by heatstroke than the natives of the country. It would be strange if it were otherwise ; as Manson writes of the natives of tropical countries, "Their physiological activities are attuned by custom and habit to the conditions to which they were born." The following table shows to what an extent this is true.

TABLE I.-Number of Admissions and Deaths from Heatstroke in Europeans in India and Natives.

\begin{tabular}{|c|c|c|c|c|c|c|}
\hline \multirow[t]{2}{*}{ Year. } & \multicolumn{2}{|c|}{$\begin{array}{c}\text { European army, } \\
\text { average strength } \\
68,000 .\end{array}$} & \multicolumn{2}{|c|}{$\begin{array}{c}\text { Native army, } \\
\text { average strength } \\
124,000 .\end{array}$} & \multicolumn{2}{|c|}{$\begin{array}{c}\text { Native prisoners, } \\
\text { average strength } \\
110,000 .\end{array}$} \\
\hline & $\begin{array}{l}\text { Admis- } \\
\text { sions. }\end{array}$ & Deaths. & $\begin{array}{l}\text { Admis- } \\
\text { sions. }\end{array}$ & Deaths. & $\begin{array}{l}\text { Admis- } \\
\text { sions. }\end{array}$ & Deaths. \\
\hline $1898 \ldots$ & 369 & 79 & 31 & 11 & 182 & 40 \\
\hline $1897 \ldots$ & 257 & 51 & 32 & 11 & 103 & 52 \\
\hline $1896 \ldots$ & 268 & 49 & 46 & 26 & 110 & 41 \\
\hline $1895 \ldots$ & 143 & 60 & 34 & 12 & 71 & 37 \\
\hline Total & 1037 & 239 & 143 & 60 & 406 & 170 \\
\hline- & \multicolumn{2}{|c|}{$\begin{array}{c}\text { Deaths per mille } \\
=3 \cdot 5 \text {. }\end{array}$} & \multicolumn{2}{|c|}{$\begin{array}{l}\text { Deatbs per mille } \\
=0.48 .\end{array}$} & \multicolumn{2}{|c|}{$\begin{array}{c}\text { Deaths per mille } \\
=1.5 .\end{array}$} \\
\hline
\end{tabular}

We now come to a consideration of the statement about new arrivals contrasted with old residents (Tables II., III., and IV.).

TABLE II.-Heatstroke in Relation to Length of Residence in India. Deaths per 1000 of Strength.

\begin{tabular}{|c|c|c|c|c|c|c|}
\hline & Year. & $\begin{array}{l}\text { First } \\
\text { and } \\
\text { second } \\
\text { year. }\end{array}$ & $\begin{array}{c}\text { Third } \\
\text { to } \\
\text { fifth } \\
\text { year. }\end{array}$ & $\begin{array}{c}\text { Sixth } \\
\text { to } \\
\text { tenth } \\
\text { year. }\end{array}$ & $\begin{array}{c}\text { Eleventh } \\
\text { to } \\
\text { fifteenth } \\
\text { year. }\end{array}$ & $\begin{array}{l}15 \text { years } \\
\text { and } \\
\text { upwards. }\end{array}$ \\
\hline 1894 & $\begin{array}{llll} & \ldots & \ldots & \ldots\end{array}$ & $1 \cdot 06$ & 0.73 & 0.44 & 0.67 & - \\
\hline 1893 & $\begin{array}{llll}\ldots & \ldots & \ldots\end{array}$ & 0.40 & 0.38 & 0.63 & - & - \\
\hline 1892 & $\begin{array}{llll}\cdots & \ldots & \ldots\end{array}$ & 100 & 0.72 & 103 & $1 \cdot 40$ & $3 \cdot 85$ \\
\hline 1891 & $\begin{array}{llll}\cdots & \ldots & \ldots\end{array}$ & $1 \cdot 74$ & 0.59 & 0.43 & 1.81 & $3 \cdot 27$ \\
\hline \multicolumn{2}{|c|}{ Average* $\ldots$} & 1.02 & 0.61 & 0.63 & 099 & 1.68 \\
\hline
\end{tabular}

Liability Percentage.

\begin{tabular}{rrrl|l|r|r|r|r}
\hline 1894 & $\ldots$ & $\ldots$ & $\ldots$ & 36 & 25 & 15 & 23 & - \\
1893 & $\ldots$ & $\ldots$ & $\ldots$ & 28 & 27 & 45 & - & - \\
1892 & $\ldots$ & $\ldots$ & $\ldots$ & 12 & 9 & 13 & 18 & 48 \\
1891 & $\ldots$ & $\ldots$ & $\ldots$ & 22 & 7 & 5 & 23 & 42 \\
\hline Average $^{*}$ & $\ldots$ & $\ldots$ & 21 & 12 & 13 & 20 & 34 \\
\hline
\end{tabular}

* Averages calculated on average strengths yearly.

TABLE III.-Heatstroke and Length of Residence. Deaths per 1000 of Strength.

\begin{tabular}{|c|c|c|c|c|c|c|c|}
\hline Year. & $\begin{array}{l}\text { Under } \\
1 \text { year. }\end{array}$ & $\begin{array}{l}1 \text { to } 2 \\
\text { years. }\end{array}$ & $\begin{array}{l}2 \text { to } 3 \\
\text { years. }\end{array}$ & $\begin{array}{l}3 \text { to } 4 \\
\text { years. }\end{array}$ & $\begin{array}{l}4 \text { to } 5 \\
\text { years. }\end{array}$ & $\begin{array}{l}5 \text { to } 10 \\
\text { years. }\end{array}$ & $\begin{array}{l}10 \text { years } \\
\text { and } \\
\text { over. }\end{array}$ \\
\hline 1895 & $1 \cdot 46$ & 0.89 & 0.97 & 028 & 0.25 & 127 & 0.54 \\
\hline 1896 & 0.63 & 0.78 & 0.69 & 0.35 & 023 & $1 \cdot 31$ & 151 \\
\hline 1897 & 2.25 & 0.44 & 054 & 0.20 & 025 & 0.34 & $1 \cdot 12$ \\
\hline 1898 & 0.87 & 1.69 & $1 \cdot 17$ & 0.63 & $1 \cdot 16$ & 149 & 1.55 \\
\hline Average... & $1 \cdot 31$ & 0.94 & 0.84 & $0 \cdot 36$ & 0.46 & $1 \cdot 12$ & $1 \cdot 19$ \\
\hline
\end{tabular}

Liability Percentage.

\begin{tabular}{rr|r|r|r|r|r|r|r}
\hline 1895 & $\ldots$ & 26 & 16 & 17 & 5 & 4 & 22 & 10 \\
1896 & $\ldots$ & 11 & 14 & 13 & 6 & 4 & 24 & 27 \\
1897 & $\ldots$ & 44 & 9 & 11 & 4 & 5 & 7 & 22 \\
1898 & $\ldots$ & 10 & 20 & 14 & 7 & 14 & 17 & 18 \\
\hline Average... & 21 & 15 & 14 & 6 & 7 & 18 & 19 \\
\hline
\end{tabular}

TABLE IV.-Heatstroke in Relation to Age. Deaths per 1000 of Strength.

\begin{tabular}{|c|c|c|c|c|c|c|c|c|}
\hline \multicolumn{3}{|c|}{ Year. } & $\begin{array}{c}\text { Under } \\
20 \\
\text { years. }\end{array}$ & $\begin{array}{l}20 \text { to } 25 \\
\text { years. }\end{array}$ & $\begin{array}{l}25 \text { to } 30 \\
\text { years. }\end{array}$ & $\begin{array}{l}30 \text { to } 3 \\
\text { years. }\end{array}$ & $\begin{array}{l}55 \text { to } 40 \\
\text { years. }\end{array}$ & \begin{tabular}{|c}
40 years \\
and up- \\
wards.
\end{tabular} \\
\hline 1898 & & $\ldots$ & 0.47 & $1 \cdot 10$ & 1.00 & $1 \cdot 71$ & $4 \cdot 24$ & 4.89 \\
\hline 1897 & $\begin{array}{lll}\ldots & \ldots\end{array}$ & $\ldots$ & - & 0.82 & 060 & $1 \cdot 16$ & - & $2 \cdot 49$ \\
\hline 1896 & $\ldots \quad \ldots$ & $\ldots$ & - & 0.53 & 0.58 & $1 \cdot 96$ & $2 \cdot 75$ & $5 \cdot 26$ \\
\hline 1895 & $\ldots \quad \ldots$ & $\ldots$ & - & 0.84 & 0.76 & $1 \cdot 88$ & $2 \cdot 20$ & - \\
\hline Aver & ge $\quad \ldots$ & $\ldots$ & 0.13 & 0.82 & 0.73 & $1 \cdot 69$ & $2 \cdot 34$ & $3 \cdot 14$ \\
\hline
\end{tabular}

